\title{
KONSEP PENDIDIKAN ANDRAGOGI MENURUT PENDIDIKAN ISLAM
}

\author{
Bakri Anwar
}

Fakultas Tarbiyah dan Keguruan UIN Alauddin Makassar

\begin{abstract}
The study that focusses on enalysing the scope of andragogi as a learning theory in educating the adults, find the andragog method. Eccrording to the Islamic learning theory, creates an application of andragogi. Theoritically, the study function to gain the concepts of learning method that can be applied to echieve the goals. The practically functions to develop the methodolgy based on Islamic education.

From the study is found that term andragogi is taken from Greek term andr that means the adult and agogus or agogos that means to lead or to guide. Andragogi is an art of teaching the adults in the learning process, an teachnique to help them to study based on their needs, and effort to motivate tham to learn by using their experience to get new learning experience. So, andragogi is a learning method that is used in educating the adults. The assumtion about andragogi are self concept about the learnes, experience role, readiness to study, and learning orientation.

The main phases of andragogi extend over creating a conducive learning, learning need diagnosis, planning process, formulating goal, developing general model, deciding learning material and its technique as well, and education learning evaluation. The principles of andragogi are readiness, sequencing understanding, participation, feedback, reinforcement, motivation, apperception, application, and transfer of learning.
\end{abstract}

Keywords:

Concept of education, Andargogi, and Islamic Education.

\begin{abstract}
Abstrak
Tujuan studi ini untuk menggali ruang lingkup andragogi sebagai teori pembelajaran bagi pendidikan orang dwasa, menemukan metode andragogi. Menurut teori pembelajaran pendidikan Islam, menggagas penerapan metode pembelajaran yang bersifat andragogis. Secara teoritis studi ini berguna untuk memperoleh konsep-konsep berupa metode pembelajran yang dapat digunakan dalam mendukung tercapinya tujuan. Dan secara praktis studi ini berguna un tuk pengembangan metodologi berbasis pendidikan Islam.
\end{abstract}


Hasil studi ini bahwa andragogi berasal dari istilah Yunani andr yang berarti orang dewasa dan agogus atau agogos yang berarti memimpin atau membimbing. Andragogi adalah seni dan ilmu mengajar orang dewasa dalam belajar, cara membantu orang dewasa belajar sesuai kebutuhannya atau upaya memotivasi orang dewasa untuk belajar menunakan pengalamannya untuk mencapai pengalaman belajar baru. Jadi andragogi adalah metode pembelajran di gunakan bagi pendidikan orang dewasa.

Asumsi-asumsi tentang andragogi yaitu konsep diri tentang peserta didik, peranan pengalaman, kesiapan untuk belajar, dan orientasi belajar. Langkah-langkah pokoknya meliputi penciptakan iklim belajar yang kondusif, diagnosis kebutuhan belajar, proses perencanaan, mempormulasikan tujuan, pengembangan model umum, meletakkan materi dan tehnik pembelajaran, dan melakukan evaluasi. Prinsipprinsipnya meliputi kesiapan untuk belajar, tahapan belajar, pemahaman, persan serta, umpan balik, pemantapan, dorogan untuk belajar, apresepsi, penerapan dan alih belajar.

Kata Kunci:

Konsep Pendidikan, Andargogi, dan Pendidikan Islam

\section{A. LATAR BELAKANG}

1-Qur'an dalam sudut pandang pendidikan Islam merupakan landasan 1 pendidikan ${ }^{1}$ yaitu pijakan yang kuat dan baik untuk membentuk 1 kepribadian manusia agar memiliki keutuhan rohani dan jasmani, sehingga dapat hidup berkembang secara wajar dan normal karena takwanya kepada Allah SWT. ${ }^{2}$ Sebab al-Qur'an mengandung ajaran paripurna, mencakup seluruh bidang kehidupan manusia,baik ibadah muamalah yang berhubungan dengan pendidikan, budaya dan aspek lainnya. Ha ini diungkapkan dalam al-Qur'an Surah al-An'Am ayat 38." Tiadalah Kami alpakan sesuatupun di dalam Al-Kitab, kemudian kepada tuhanmulah mereka dihimpunkan".

Di samping al-Qur'an, hadits Nabi Muhammad SAW juga, sebagai landasan pendidikan Islam, sebagaimana dalam al-Qur'an dikatan dala Surah Al-Ahzab ayat: 21." Sesungguhnya pada diri Rasulullah suri tauladan yang baik bagimu (yaitu) bagi orang yang menghrap (rahmat)Allah dan kedatangan hari kiamat dan dia banya". Penjelasan tersebut menegaskan bahwa totalitas diri Rasul SAW, harus menjadi contoh, model, dalam mendidik baik secara pedagogik maupun mendidik secara andragogi. Pada konteks inilah metode pembelajaran sangat penting dikembangkan dalam berbagai jenis, dan jenjang pendidikan.Terkait dengan hal ini, Ahmad Zain An Najah dalam tulisannya tentang Sukses belajar mengemukakan beberapa kaidah umum dalam

\footnotetext{
${ }^{1}$ Zakiah Drajat, dkk., Ilmu pendidikan Islam (cet. V; Jakarta: Bumi Aksara, 2004),h.19

2 Ibid, h.29.
} 
belajar, di antaranya adalah:" أهم من المآدةالطريقة " (Pengetahuan tentang metode pengajaran jauh lebih penting dari pada materi pelajaran itu sendiri). ${ }^{3}$

Secara garis besar dapat ditangkap makna kaidah ini bahwa seorang penuntut ilmu hendaknya lebih dahulu memperhatikan dan mempelajari tata cara, metode, tentang kiat-kiat belajar dengan benar yang efektif dan efesien, sebelum mempelajari materi pendidikan. Secara teoritik pembelajran adalah salah satu faktor penting dalam pendidikan, sebab keberhasilan pembelajaran dapat dilihat dari seberapa bisa peserta didik mengerti suatu masalah melalui semua tahap proses belajar.

Berdasarkan berbagai pandangan di atas, studi ini dilakukan untuk menggali konsep andragogi yang terdapat dalam al-Qur'an dan hadits, seta landasan kuat yang menjadi rujukan pendidikan Islam guna pengembangan metode pembelajran. Dalam beberapa pandangan tentang konsep pendidikan Andragogi adalah menurut Malcolm Knowles dalam The Adult Learner, A Neglected Species adalah teori belajar yang tepat bagi orang dewasa. Dan dalam kamus Besar Bahasa Indonesia yaitu ilmu tentang tata cara orang dewasa belajar, dalam presfektif terminologi, Knowles menggambarkan peserta didik sebagi orang dewasa, diasumsikan memiliki kemampuan aktif merencanakan arah, memiliki bahan, menyimpulkan, dan mampu mengambil manfaat dengan cara terbaik untuk belajar, menganalisa, dan menyimpulkan dan mampu mengambil manfaat dari pendidikan, fungsi pendidikan sebagai fasilitator bukan menggurui.oleh karena itu, relasi pendidik dan peserta didik bersifat multikumunikasi.

\section{B. RUMUSAN MASALAH}

Berdasarkan dari latar belakang diatas maslah pokok dalam tulisan ini" mengapa metode Andragogi perlu dikembangkan dan pendidikan Islam "Untuk mengkaji masalah ini penulis merumuskan sub masalah sebagai berikut:

a. Bagaimana ruang lingkup andragogi sebagai metode pembelajaran?

b. Bagaimana penerapan metode andragogi menurut teori pembelajaran dalam berbagai pelatihan?

c. Bagaimana pengembangan metode andragogi menurut teori pembelajaran pendidikan Islam?

C. TUJUAN PENELITIAN

a. Untuk mengetahui ruang lingkup andragogi sebagai metode pembelajan.

b. Untuk mengetahui penerapan metode andragogi menurut teori pembelajran dalam berbagai pelatihan.

c. Untuk mengetahui pengembagan metode angragogi menurut teori pembelajaran pendidikan Islam.

\footnotetext{
${ }^{3}$ Ahmad Zain, sukses belajar halaman 10 .
} 


\section{MANFAAT PENELITIAN}

Penelitian ini diharapkan dapat meningkatkan kompetensi pendidik dalam mengajar di berbagai jenjang pendidikan, terutama dalam mengajar orang yang sudah dewasa, menguasai metode dan cara penerapannya dalam pembelajaran. Penelitian ini bermanfaat juga dalam pembelajaran berupa pelatihan-pelatihan guru, pelatihan ASN dan sebagainya.

Penelitian ini juga diperuntukkan bagi mereka yang ingin menguasai meode dan teori-teori pembelajaran bagi orang dewasa, dan juga bagi mereka yang mencari pengembangan teori pembelajaran yang lebih menyenangkan, efektif dan efesien, menjadikan siswanya lebih aktif berfikir dan berkreasi.

Secara teoritik studi ini bermanfaat:

1. Memiliki konsep-konsep berupa metode pembelajaran yang dapat digunakan dalam mendukung tercapainya tujuan pembelajaran sehingga perlu melakukan kajian terhadap metode pembelajaran yang dikembangkan dalam berbagai konsep pendidikan, termasuk konsep metode pembelajaran dalam pendidikan Islam

2. Dapat membatu pembelajaran dalam mengembangkan metodologi dalam rangka memperbaiki, menata ulang, atau menyempurnakan paradigma atau paling tidak menambah khazanah pengetahuan dan keterampilan bagi pendidik dalam rangka mengembangkan metode pembelajaran yang lebih tepat.

Secara praktis studi ini bermanfaat:

1. Pengembangan metodologi pengajaran yang berbasis pada pendidikan Islam.

2. Sumbangan ilmiah menyangkut menyangkut pengembangan metode pembelajran dalam ruang belajar masyarakat akademik yang lebih relevan, partisipatif, egaliter, dan manusiawi guna peningkatan kulitas pendidikan di Indonesia pada umumnya

\section{E. TINJAUAN PUSTAKA}

Andragogi sebagai metode pembelajaran dapat dijumpai dari beberapa literatur yang di tulis oleh para pakar pendidikansejak tahun 1980 seiring dengan beberapa kebutuhan universitas di Indonesia yang membuka bidang studi pendidikan di luar sekolah.

Dalam karya Malcom Knowles dengan judul The modern Practise of Adult Education Andragogi Versus Pedagogi. ${ }^{4}$ Menurut Ny Tisnowati Tamat sebagai pakar pendidikan mengemukakan bahwa penyelenggaraan pendidikan dan pelatihan yang dilakukan oleh instansi pemerintah dan swasta agar mendapatkan hasil yang maksimal diperlukan cara dan metode yang berbeda sebagai mana dilakukan oleh pendidikan formal, cara yang dimaksud adalah metode pembelajran partisipatif, dan istilah andragogik lawan dari pedagogik

\footnotetext{
${ }^{4}$ Ny. Tisnowati Tamat, Dari pedagogik ke Andragogik (Jakarta: Pustaka Dian, 1983) h.5
} 
Mernurut Ny Tisnowati Tamat, metode andragogi yang diterapkan dalam pendidikan dan pelatihan akan berhasil, sebab metode pembelajaran lebih relevan dengan tugas peseta pelatihan, dan dapat bekerja dengan baik setelah pendidikan dan pelatihan dan dapat mengarahkan diri sendiri dan tidak terlalu bergantung pada berbagai bentuk bimbingan dan pengawasan.

Dalam konsep pendidikan orang dewasa, A.G. Lunandi berpendapat bahwa orang dewasa bukan anak kecil, maka pendidikan nbaginya tidak disamakan dengan anak sekolah, pendidikanorang dewasa untuk memperbaiki metode-metode lama yang tidak relevan lagi. Menurut Zainudin Arif mengemukakan dalam tulisannya konsep andragogi yaitu suatu ilmu dan seni dalam membantu orang dewasa belajar. Dengan asumsi dasar, bahwa orang dewasa berbeda dengan anak-anak secara psikologik dan pengalaman hidupnya, maka metode pembelajaran orang dewasa berbeda dengan metode pembelajran anak-anak. Selama ini ada kecenderungan pendapat mengatakan metode pembelajaran anak-anak dan orang dewasa sama saja. Akan tetapi dengan adanya konsep andragogi akan lebih jelas bahwa pembelajaran orang dewasa dan anak-anak jauh berbeda.

Dalam berbagai literatur yang telah penulis kemukakan di atas, terdapat berbagai pandangan yang seakan-akan berbeda tentang andragogi. Ada yang berpendapat bahwa andragogi sebagai metode pembelajran dan ada juga berpendapat bahwa andragogi sebagai suatu pendekatan dalam pendidikan. Demikian juga penyebutannya, di mana Ny. Tisnowati Tamat menulisnya dengan andragogik, sedangkan Zainuddin Arif menulisnya dengan" Andragogi "sementara A.G. Lunandi dan H. Suprijanto memilih nama "Pendidikan Orang Dewasa"

Sesunggunya jika ditelusuri lebih jauh, aspek pemaknaan sesungguhnya berintisari sama yaitu ilmu dan seni pembelajaran orang dewasa.

\section{F. PEMBAHASAN}

\section{a. Pengertian Andragogi}

Malcom S. Knowles dalam bukunya The Modern Practice of Adult Education, Andragogi Versus Pedagogy mengnkapkan bahwa paradigma belajar berkembang selama ini lahir dari hasil studi terhadap perilaku belajar anak-anak dan bintang. Demikian pula konsep mengajar merupakan hasil pengalaman mengajar anak-anak. Sehingga lahir teori mengenai pembelajaran mengenai pembelajaran didasarkan kepada rumusan pendidikan sebagai suatu proses transmisi budaya. Dari teori tersebut muncullah istilah pedagogi yang diartikan sebagai suatu ilmu idan seni dalam mengajar anak-anak, dan selanjutnya menjadi ilmu dan seni mengajar anakanak $^{5}$

Teori pedagogi yang bersifat transmisikan pengetahuan berhadapan dengan berbagai perubahan yang terjadi begitu cepat di abad modern ini sehingga

${ }^{5}$ Zainudddin Arif, Andragogi (Cet: II; Bandung: Angkasa, 1994), h.1 pedagogi sering diartikan sebagai ilmu pendidikan ilmu pengajaran, lihat Departemen Agama dan Kebudayaan R.I. h. 657. 
pengetahuan yang diperoeh seseorang mengalami penurunan fungsi ditengah kemajuan inovasi terknologi, mobilitas penduduk, perubahan sistem ekonomi dan politik, oleh karenanya pendidikan tidak tepat lagi dirumuskan sebagai upaya mentransmisikan pengetahuan melainkan dirumuskan sebagai suatu proses penemuan sepanjang hayat terhadap apa yang dibutuhkan untuk diketahui.

Dalam sebuah pandangan paradigma baru bahwa dalam belajar, baik bagi anak-anak maupun orang dewasa yang terpenting adalah bagaimana mempelajari keterampilan-keterampilan tertentu untuk dapat mengarahkan diri sendiri menemukan sesuatu yang baru, dan bagaimana mengarahkan diri sendiri untuk selalu bertanya dan mencari jawabnnya. Perubahan konsep tersebut selanjutnya mempengaruhi teori pembelajaran pedagogi. Dan dikalangan pedagogi (ahli pedagogi) mencari alternatif metode pembelajaran, sebagai timbulnya penelitian tentang belajar orang dewasa setelah perang dunia ke-II dan ditemukan teori baru dengan nama andragogi. ${ }^{6}$

Andragogi secara etimologis adalah sebagai teori pembelajaran sangat penting untuk diketahui dan dipahami, sebab paradigma tentang pembelajaran yang didasarkan pada rumusan pendidikan sebagai sebagai suatu proses transmisi budaya, yang melahirkan pedagogi yaitu ilmu dan seni mengajar anak-anak. Orang dewasa yang dimaksud secara fisik (biologis) adalah cukup berumus. ${ }^{7}$ secara etimologis, andragogi berasal dari bahasa Yunani, yaitu andra yang berarti orang dewasa dan agogus yang berarti memimpin atau membimbing. ${ }^{8}$ Menurut Zainudin Arif mengemukakan dalam tulisannya konsep andragogi yaitu suatu ilmu dan seni dalam membantu orang dewasa belajar. ${ }^{9}$ Dengan demikian pengertian andragogi adalah seni dan ilmu mengajar orang dewasa, cara membantu orang dewasa belajar menggunakan pengalamannya untuk mencapai pengalaman belajar baru. Istilah andragogi oleh A.G.Lunandi istilah pendidikan orang dewasa adalah: Istilah pendidikan orang dewasa berarti keseluruhan proses pendidikan yang diorganisasikan, apapun isi tingkatan dan metodenya, baik formal maupun tidak,yang melanjutkan maupun menggantikan pendidikan semula di sekolah, kelas dan universitas serta latihan kerja,yang membuat orang yang dianggap dewasa oleh masyarakat mengembangkan kemampuannya, memperkaya pengetahuannya, meningkatkan kualifikasi teknis atau profesionalnya, dan mengakibatkan perubahan pada sikap dan perilakunya dalam prepektif rangkap perkembangan pribadi secarah utuh dan partisipasi dalam perkembangan sosial, ekonomi dan budaya yang

${ }^{6}$ Ny tisnowati Tamat, dari Pedagogi ke Andragogy pedoman bagi pengelola pendidikan dan latihan (cet.I; Jakarta: Pustaka pelajar 1985), h.15

${ }^{7}$ Menurut R. J. Havingurst masa dewasa dibagi tiga fase yaitu: dewasa awal 18-30 tahun, dewasa pertengahan 30-55 tahun, dewasa akhir $5 \overline{5}$ tahun, lihat W.S. Winkel psikologi pengajaran (Jakarta: Grasindo), 1991), h.9

\footnotetext{
${ }^{8}$ Zainuddin Arif, op.cit., h. 2.

${ }^{9}$ M. Thoyib, Pengantar Pendidikan orang dewasa (Jakarta: Depsos R.I., 2006) h. 1.
} 
seimbang dan bebas $^{10}$ Konsep Adult Education yang dikemukakan di atas ditujuakan pada jenis program pendidikan seperti: pendidikan bekal kerja bagi para pencari kerja untuk memasuki lapangan kerja dan rogram pendidikan kader dalam sebuah organisasi politik dan masyarakat untuk mengembangkan oragnisasinya.

\section{b. Proses Lahirnya Andragogi}

Proses lahinya Andragogi menurut Malcolm Knowles adalah: Antara tahun 1929 sampai 1948 di Amerika terbit jurnal American Association For Adult Education, yaitu sebuh jurnal berkaitan dengan pendidikan orang dewasa. Kemudian pada tahun 1950 para pedagogi mulai menerbitkan tulisan-tulisannya mengenai pendidikan orang dewasa. Istilah Andragogi pertama kali dikenalkan melalui karya seorang ahli pendidikan bagi orang dewasa berkebangsan Yugoslavia dalam buku yang berjudul Adult Leadership tahun 1968. Andragogi juga pertama kali digunakan oleh Alexander Kapp pada tahun 1883 untuk merumuskan konsepkonsep dasar teori pendidikan. Kapp tetap membedakan antara pengertian social pedagogy yang menyiratkan arti pendidikan orang dewasa dengan andragogy. ${ }^{11}$ Dalam rumusan Kapp “ Social Pedagogy “ merupakan proses pendidikan pemulihan ( remedial) bagi orang dewasa yang cacat. Adapun andragogi justru lebih merupakan proses pendidikan bagi seluruh orang dewasa, cacat atau tidak cacat secara berkelanjutan.

Pendekatan andragogi mulai berpengaruh dalam dunia pendidikan di Indonesia sejak munculnya kebutuhan beberapa universitas yang membuka bidang studi pendidikan luar sekolah di tahun 1980, dari sinilah kemudian mulai beberapa ahli pendidikan menerjemahkan beberapa buku yang membahas tentang andragogi.

\section{c. Perkembangan Andragogi}

Sebelum muncul andragogi, yang digunakan dalam pembelajaran adalah pedagogi. konsep ini menempatkan peserta didik sebagai obyek di dalam pendidikan, mereka mesti menerima pendidikan yang sudah dirancang oleh pendidik. Apa yang dipelajari, materi akan diterima, metode penyampaiannya, dan lain-lain, semua tergantung kepada pendidik dan tergantuk kepada sistem pendidikan. Dalam hal ini peserta didik tidak lebih dari sebagai obyek dari pendidikan.

Kelemahan pedagogi adalah peserta didik yang memiliki keunikan, talenta, minat, kelebihan, menjadi tidak berkembang,tidak bisa mengesplorasi kemampuan dirinya, bahkan tidak mampu menyampaikan kebenarannya sendiri, seakan - akan yang memiliki kebenaran adalah masa lalu, perbedaan bukanlah menjadi hal yang

10 A.G. Gunandi, Pendidikan orang dewasa (Cet.VII; Jakarta: P.T. Gramedia Pustaka Utama, 1993), h. Viii.

11 Supriadi, “Andragogy ( sbuah konsep teoritik), “ Pendidikan Network, MSI-UII.Net 21 Maret 2006, h.2. 
biasa, melainkan jika ada yang berbeda itu akan dianggap sebagai sebuah perlawanan. ${ }^{12}$

Kelebihan pedagogi, yaitu dapat menjaga mata rantai keilmuan yang sudah di awali oleh orang-orang terdahulu, mata rantai keilmuan bisa berkelanjutan oleh generasi mendatang. Genrasi mendatang tidak mulai nari nol melainkan melanjutkan apa yang sudah ada. Dalam andragogi di kenal istilah-istilah Enjoy Learnig, Workshop, Out bound dan lain-lain ${ }^{13}$ dari konsep andragogi inilah kemudian muncul konsep-konsep Liberalisme Pendidikan dan Anarkisme pendidikan. Liberalisme pendidikan, bertujuan jangka panjang untuk melestarikan dan memperbaiki tatanan sosial yang ada dengan cara mengajar setiap siswa sebagaimana cara menghadapi persoalan-persoalan sehari-hari secara efektif.

Anarkisme pendidikan pada umumnya menerima sistem penyelidikan eksperimental yang terbuka. Anarkisme pendidikan beranggapan bahwa harus meminimalkan atau menghapus pembetasan-pembatasan kelembagaan terhadap perilkau personal. Menurut anarkisme pendidikan, pendekatan terbaik adalah pendekatan yang mengupaya untuk mempercepat perombakan humanistik berskala besar dengan cara menghapus sistem persekolahan. Disinilah dibutuhkan satu pendekatan andragogi yang bersifat partisipatif.

Menurut Malcolm Knowles mengemukakan empat asumsi pokok andragogi yaitu: konsep tentang peserta didik, fungsi pengalaman peseta didik, kesiapan belajar dan orientasi belajar.

\section{Konsep tentang Peserta Didik (Konsep diri)}

Asumsi bahwa kesungguhan dan kematangan diri seseorang bergerak dari ketergantugan total, menuju ke arah pengembangan diri sehingga mampu untuk mengarahkan dirinya sendiri dan mandiri. Dengan kata lain bahwa secara umum konsep diri anak-anak masih tergantung kepada orang tua sedang pada oarang dewasa konsep dirinya sudah mandiri. Karena kemandirian inilah orang dewasa membutuhkan dan memperoleh penghargaan orang lain sebagai manusia yang mampu menentukan dirinya sendiri, mampu mengarahkan dirinya sendiri.

Apabila orang dewasa tidak menemukan dan menghadapi situasi dan kondisi yang memungkinkan timbulnya penentuan diri sendiri dalam suatu pwmbelajaran maka akan menimbulkan reaksi yang kurang menyenangkan. Orang dewasa juga punya kebutuhan psikologis agar secara umum menjadi mandiri, meskipun dalam situasi tertentu boleh jadi ada ketergantugan bersifat sementara.

2. Fungsi pengalaman

Asumsinya adalah bahwa sesuai dengan perjalanan waktu seseorang individu 2007 h. 3

12 Bambang S. dan Lukman, "Teori belajar Andragogi” Pendidikan network-MSI-UII.Net, 23 Maret

13. Marthias Finger dan Jose Manuel Asun, Adult Education at theCrossroads, diterjemahkan oleh Nining Fatikasari dengan judul Quo vadis pendidikan orang dewasa (cet.I; Yogyakiarta; Pustaka Kendi, 2004) h. 15 . 
tumbuh dan berkembang menuju arak kematangan. Dalam perjalanannya seorang individu mengalami dan mengumpulkan berbagai pengalaman pahitnya kehidupan, hal ini menjadikan seseorang sebgai sumber belajar dan pada saat yang bersamaan individu juga memberikan dasar yang luas untuk belajar dan pengalaman baru. Oleh sebab itu dalam pembelajaran orang dewasa, terjadi penurunan pengunaan teknik transmittal seperti yang digunakan dalam metode pembelajaran konvensional dan menjadi lebih mengembangkan tehnik yang bertumpu pada pengalaman.

3. Kesiapan Belajar

Asumsinya bahwa setiap individu semakin menjadi matang sesuai dengan perjalanan waktu, maka kesiapan belajar bukanlah ditentukan oleh kebutuhan atau paksaan akademik ataupun biologisnya, akan tetapi lebih banyak ditentukan oleh tuntutan perkembangan dan perubahan tugas dan peran sosialnya. Seorang anak belajar karena adanya tuntutan akademiknya, tapi seorang dewasa siap belajar sesuatu karena tingkatan perkembangan mereka yang harus dihadapi dalam peranannya sebagai pekerja, orang tua ataupun pimpinan organisasi. Dalam hal ini tentunya materi pembelajaran perlu disesuaikan dengan kebutuhan yang sesuai dengan peran sosialnya.

4. Orientasi belajar

Yaitu bahwa anak orientasi belajarnya seolah-olah sudah ditentukan dan dikondisikan untuk memiliki orientasi yang berpusat pada materi pembelajaran. Sedangkan pada orang dewasa mempunyai kecenderungan memilki orientasi belajar yang berpusat pada pemecahan masalah yang dihadapi.

Bagi orang dewasa belajar lebih bersifat untuk dapat dipergunakan dalam waktu segera, sedangkan anak masih menunggu waktu hingga dia lulus. Bahwa untuk anak kecenderungan belajar hanya untuk lulus.

\section{d. Langkah-langkah pokok dalam Andragogi}

Berdasarkan pada implikasi angragogi untuk praktek dalam pembelajaran kegiatan pelatihan, maka perlu ditempuh langkah-langkah pokok sebagai berikut:

1. Menciptakan lingkungan belajar yang kondusif

Ada beberapa hal pokok yang dapat dilakukan dalam upaya menciptakan iklim yang kondusif yaitu:

a. Penataan dan peralatan hendaknya disesuaikan dengan kondisi orang dewasa

b. Alat peraga dengar dan lihat yang dipergunakan hendaknya disesuaikan dengan kondisi fisik orang dewasa.

c. Penataan ruangan, pengaturan meja, kursi dan peralatan lainnya hendaknya memungkinkan terjadinya interaksi sosial.

2. Pengaturan lingkungan sosial dan psikologi

Iklim psikoogis hendaknya merupakan salah satu faktor yang membuat orang dewasa merasa diterima, dihargai dan didukung dengan cara:

a. Fasilitator lebih bersifat mendukung dan membantu 
b. Mengembangkan suasana bersahabat, informal dan santai melalui kegiatan permainan yang sesuai

c. Menciptakan suasana yang demokratis dan kebebasan menyatakan pendapat tanpa rasa takut.

d. Mengembangkan semagat kebersamaan

e. Menuyun kontrak belajar yang disepakati.

3. Peran evaluasi pembelajan

Ada beberapa pokok dalam melaksanakan evaluasi hasil belajar bagi orang dewasa yakni:

a. Evalusi hendaknya beriorentasi pada pengukuran perubahan perilaku setelah mengikuti proses pembelajaran.

b. Sebaiknya evalausi dilakukan melalui pengujian.

c. Perubahan perilaku merupakan tolak ukur keberhasilan.

d. Ruang lingkup materi evalusi ditetapkan bersama secara partisipatif

e. Evaluasim dilakukan untuk menilai efektifitas dan efesiensi yang mencakup kekuatan maupun kelemahan program.

\section{d. Metode Pembelajaran Andragogi Dalam Pendidikan Islam}

a. Metode Ceramah (The Lecture Method)

Metode ceramah sering disebut metode kuliah, dapat pula disebut metode deskripsi. Metode ceramah merupakan metode yang memberikan penjelasan atau memberi deskripsi lisan secara sepihak tentang materi pembelajaran. Metode ini tidak cocok bagi orang dewasa, karena orang dewasa menghendaki keterlibatan aktif dalam semua aktifitas.

b. Brainstorming (curah pendapat)

Metode ini adalah metode umum yang digunakan dalam pembelajaran untuk membantu peserta didik memikirkan sebanyak mungkin ide dan gagasan. ${ }^{14}$ Selama berlangsungnya curah pendapat peserta didik didorong dapat menghasilkan pendapat, gagasan secepat mungkin tanpa perlu memikirkan nilai dari pada pendapat itu, tekanannya pada kuantitas, dan bukan kualitas.

c. Metode diskusi (Discussion Method)

Metode diskusi adalah metode yang biasanya digunakan dalam andragogi, karena bersifat partisifatif untuk menyumbangkan pemikiran, gagasan, dalam kegiatan diskusi, kalau metode ceramah hanya tejadi satu arah akalu metode diskusi terjadi banyak arah. Metode diskusi biasanya dihadapkan pada suatu masalah yang disodorkan oleh fasilitator. Atau peserta didik menentukan topik untuk dipecahkan bersama.

${ }^{14}$ Badan litbang Agama dan diklat keagamaan, pendekatan Andragogi dalam diklat (Jakarta: Pusdiklat tenaga teknis Keagamaan,2003), h.17. 


\section{e. Prinsip-prinsip belajar Andragogi}

Belajar merupakan kegiatan mental yang tidak tampak prosesnya, yang dapat diketahui secara nyata adalah hasil belajar sebagai akibat dari proses belajar itu. Bebeapa hal yang mempengaruhi dan mendukung kemudahan dalam proses belajar sehingga mencapai hasil belajar yang diinginkan. Adapun prinsip-prinsip belajar orang dewasa adalah:

a. Kesiapan untuk belajar

Peserta didik mencapai hasil belajar yang baik, apabila sebelumnya pendidik menyiapkan kondisi peserta didik baik secara fisik maupun mental, penyediaan kondisi fisik dapat diwujudkan dengan penyediaan sarana yang sesuai dengan tujuan pembelajaran, sedangkan persiapan seara mental dapat dilakukan dengan ice breaking (mencairkan suasana) sebelum masuk meteri pembelajaran

b. Participation (peran serta)

Belajar dapat terjadi bila ada peran serta peserta didik yang aktif baik secara fisik maupun mental, oleh karena itu ruang kelas peserta didik perlu di atur agar dapat memberikan keleluasaan dalam pembelajaran, seperti tempat duduk mudah dipindahkan, adanya LCD dan lain-lain.

c. Application (penerapan)

Belajar akan lebih mudah jika peserta melihat relevansinya yang dapat diterapkan pada lapangan kerja. Aplikasi merupakan salah satu hal yang harus terjadi dalam pembelajran setelah sebelumnya didahului dengan pengertian dan pemahaman dasarnya. Oleh karenanya perlu diciptakan metode pembelajran yang menarik.

d. Transfer of Learning (Alih belajar)

Melalui tahap aplikasi, dimungkinkan dapat sampai pada tahap gineralisasi yaitu pemampaatan hasil belajar untuk dapat belajar dalam keadaan lain. Berkaitan dengan prinsip-prinsip belajar orang dewasa tersebut maka pendidik sangat penting memiliki sikap sebagai berikut:

1. Empaty

Empaty adalah sikap dalam diri seseorang yang mampu menghargai dan menyelami perasaan orang lain, mampu merasakan apa yang dirasakan orang lain.

2. Kewajaran

Bersikap jujur, apa adanya, membuka diri, serta memberikan respon yang tulus. Hal ini memliki arti bahwa pendidik harus mengedepankan sikap untuk dapat menerima peserta didik dengan tulus.

3. Respek

Pandangan positif terhadap peserta didik, dengan penuh pengertian, tidak segan memberikan penghargaan dengan kemampuan peserta, dalam konteks ini 
adalah keramah-tamahan terhadap peserta didik, sehingga pembelajran berjalan tanpa ada tekanan-tekanan apapun.

4. Komitmen dan kehadiran

Pendidik terlibat penuh dengan peserta didik dalam segala keadaan, artinya pendidik menghadirkan dirinya secara utuh ditengah-tengah peserta didik.

5. Membuka diri

Menerima orang lain tanpa menilai dengan ukuran, konsep dan pengalaman diri-sendiri, memperkenalkan diri pada orang lain dengan terbuka, artinya pendidik menghargai peserta didik dengan kemampuan masing-masing.

6. Tidak menggurui, tidak menjadi ahli, tidak memutus bicara, tidak diskrimintif dan harus berpenampilan menarik.

Dalam konteks ini pendidik dituntut untuk dewasa dalam berpendapat, ataupun merespon peserta didik sehingga tidak menggurui apalagi menjadi ahli, dalam mengajar upaya memotivasi peserta didik merupakan sikap yang mendidik. Dalam teori pendidikan perbuatn tersebut merupakan metode pembelajaran.

Oleh karena itu, konsep lain yang juga menjadi pertimbangan penggunaan media adalah teori tentang kemampuan mengibagat setiap peserta didik, hasil riset Harvard Business Shool yang dikemukakan oleh Rigg sebagaimana dikutip oleh P.M. Marpaung sebagai berikut:

$10 \%$ kita mengetahui apa yang di baca

$20 \%$ kita mengetahui apa yang didengar

$30 \%$ kita mengetahui apa yang dilihat

$50 \%$ dari apa yang dilihat dan didengar

$80 \%$ dari apa yang diucapkan

$90 \%$ dari apa yang diucapkan dan dilihat. ${ }^{15}$

Hasil reset ini menunjukkan besarnya kegunaan alat bantu dalam pembelajaran untuk mendukung metode pembelajran dan menciptakan pembelajran yang bersifat aktif dan partisipatif, untuk mencapai pembelajan secara efektif.

\section{f. Pengembangan Metode Andragogi Berbasis Teori Pembelajaran Pendidikan Islam.}

Dalam konsep dasar tentang andragogi dapat disimpulkan sebagai berikut:

1. Andragogi adalah seni dan ilmu mengajar orang dewasa untuk belajar.

2. Andragogi adalah cara membantu orang dewasa belajar sesuai kebutuhannya.

3. Andragogi adalah upaya memotivasi orang dewasa belajar menggunakan pengalamannya untuk mencapai pengalaman belajar baru.

${ }^{15}$ Bobbi DePorter Mark Reardon Sarah Singer-Nourie "Quantum Teaching“ Memperaktikkan Quanrum Learning diruang-ruang kelas, Bnadung, Kaifa 2010, h. 94. 
Pandangan tersebut dilihat dari sudut ilmu pendidikan adalah konsep didaktik metodik, ${ }^{16}$ atau metode pembelajaran. Sebab seni dan ilmu mengajar, cara membantu orang belajar, dan upaya memotivasi orang untuk belajar menunjukkan perbuatan yang bersifat pendidikan dan pengajaran. Dalam pembahasan ini kita akan merujuk konsep metode pendidikan dalam al-Qur'an dan metode Nabi Muhammad saw. Dalam mengajar hadis kepada para sahabat, serta beberapa konsep ijtihad ulama dalam mempelajri ajaran Islam.

Metode pembelajaran mempunyai posisi penting dalam pencapaian tujuan pendidikan sebab metode merupakan sarana kebermaknaan materi dalam pembelajaran. Seiring dengan peubahan paradigma pendidikan, dari teaching to learning konsep pengajaran telah ditinggalkan dan diganti dengan pembelajaran, yang fokus utamanya adalah memberikan perhatian terhadap peserta didik. Berkaitan dengan hal ini maka perlu upaya serius dan sistimatis untuk menggali beberapa metode pembelajaran yang relevan dengan suasana pembelajaran orang dewasa dalam al-Qur'an dan hadis, dan pemikiran para ulama.

1. Metode pembelajaran dalam al-Qur'an.

Dalam term yang populer bahwa kata "Qalam" di dalam al-Qur'an adalah merupakan simbol dalam pendidikan Islam. Allah berfirman:

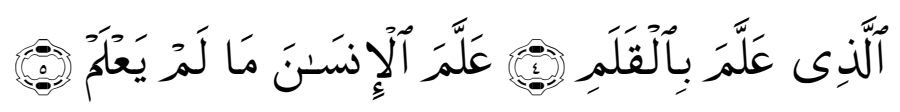

Artinya:

"Yang mengajar (manusia) dengan perantaran kalam. Dia mengajar kepada manusia apa yang tidak diketahuinya.

Maksudnya: Allah mengajar manusia dengan perantaraan tulis baca. M.Quraish Shihab menyatakan bahwa kedua ayat ini menjelaskan dua cara (metode) yang ditempuh Allah swt. Dalam mengajar manusia. Pertama melalui pena (tulisan) yang harus dibaca manusia, dan yang kedua melalui pengajaran secara langsung tanpa alat. Menurut para mufassir, Qalam merupakan simbol metode pembelajaran Allah swt kepada manusia yang ternyata metode tersebut terbukti paling leluasa dan lebih mengesankan dalam pembelajaran.

2. Metode Pemahaman.

Inti dari metod ini adalah pemahaman peserta didik terhadap apa yang dipelajari. Oleh karena itu peran akal (rasio) menjadi sangan urgen. Al-Qur'an banyak menggunakan retorika yang bervariatif untuk menggunakan akal untuk berfikir, makanya orang dewasa merasa puas jika ilmu yang didapat diketahui sumbernya, dasar hukumnya, dan landasan pemikirannya. Penggunaan akal ini dapat dipahami melalui dialog Nabi Ibrahim: Allah berfirman (2: 260).

\footnotetext{
${ }^{16}$ S. Nasution, didaktik Asas-Asas Mengajar (Jakarta: Bumi Aksara, 2000) h.1.
} 


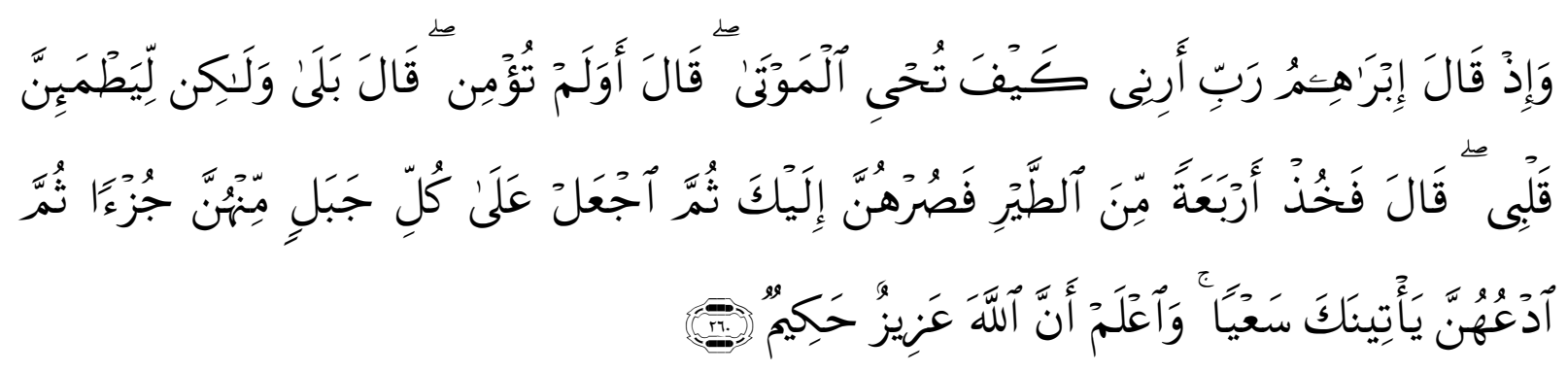

Artinya:

dan (ingatlah) ketika Ibrahim berkata: "Ya Tuhanku, perlihatkanlah kepadaku bagaimana Engkau menghidupkan orang-orang mati." Allah berfirman: "Belum yakinkah kamu?" Ibrahim menjawab: "Aku telah meyakinkannya, akan tetapi agar hatiku tetap mantap (dengan imanku) Allah berfirman: "(Kalau demikian) ambillah empat ekor burung, lalu cincanglah [165] semuanya olehmu. (Allah berfirman): "Lalu letakkan diatas tiap-tiap satu bukit satu bagian dari bagian-bagian itu, kemudian panggillah mereka, niscaya mereka datang kepadamu dengan segera." dan ketahuilah bahwa Allah Maha Perkasa lagi Maha Bijaksana. ${ }^{17}$

Ayat ini dicermati dengan pendekatan andragogis, sarat makna metode pembelajaran yang mengedepankan rasio. Dalam posisi ini jelas merupakan Nabi Ibrahim adalah orang dewasa, salah satu ciri yang ditunjukkannya adalah menggunakan rasio dalam upaya-upaya mengetahui rahasia ciptaan Tuhannya yang ada di alam. Pertanyaanya direspon positif yang maha kuasa sehungga imannya semakin teguh.

\section{Metode Penyadaran}

Konsep metode penyadaran dalam pendidikan Islam dapat dicermati dari beberapa ayat dalam al-Qur'an yang pada intinya membangun kesadaran berpesan kepada kebaikan, kesabaran dan kedamaian, memberi nasihat, ancaman, ganjaran pahala, hukuman dan pengendalian hawa nafsu. (51:55)

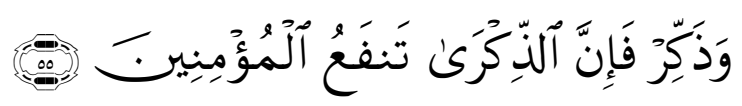

Artinya:

Dan tetaplah memberi peringatan, karena Sesungguhnya peringatan itu bermanfaat bagi orang-orang yang beriman.

${ }^{17}$ [165] Pendapat diatas adalah menurut At-Thabari dan Ibnu Katsir, sedang menurut Abu Muslim Al Ashfahani pengertian ayat diatas bahwa Allah memberi penjelasan kepada Nabi Ibrahim a.s. tentang cara Dia menghidupkan orang-orang yang mati. Disuruh-Nya Nabi Ibrahim a.s. mengambil empat ekor burung lalu memeliharanya dan menjinakkannya hingga burung itu dapat datang seketika, bilamana dipanggil. Kemudian, burung-burung yang sudah pandai itu, diletakkan di atas tiap-tiap bukit seekor, lalu burung-burung itu dipanggil dengan satu tepukan/seruan, niscaya burung-burung itu akan datang dengan segera, walaupun tempatnya terpisah-pisah dan berjauhan. Maka demikian pula Allah menghidupkan orang-orang yang mati yang tersebar di mana-mana, dengan satu kalimat cipta hiduplah kamu semua pastilah mereka itu hidup kembali. Jadi menurut Abu Muslim sighat amr (bentuk kata perintah) dalam ayat ini, pengertiannya khabar (bentuk berita) sebagai cara penjelasan. Pendapat beliau ini dianut pula oleh Ar Razy dan Rasyid Ridha. 
Pesan yang diharapkan dalam ayat ini adalah seorang pendidik dan peserta didik tidak perlu merasa lebih di antara keduanya, karena keduanya saling memberi lmu dan pengetahuan. Dalam suasana pendidikan orang dewasa, kondisi antara pendidik dan peserta didik tidak dibatasi oleh usia, pengetahuan, pengalaman, dan sikap maka sikap saling memperingati sangat dibutuhkan dalam membangun konsekwesi pendidikan orang dewasa.

Sebagaimana dipahami bahwa kebiasan mempunyai pengaruh yang besar dalam kehidupan senabaik positif maupun negatif. Kebiasaan yang baik sangat membantu dalam membentuk kepribadian, demikian juga kebiasaan yang kurang baik sangat dominan dalam menggagalkan nila-nilai yang ditanamkan. Dalam kaitan dengan metode penyadaran ini, al-Qur'an menunjukkan metode yang sistimatis melalui tahapan-tahapan. Contoh yang dikemukakan adalah menghilangkan kebiasaan buruk minuman kahamar bagi komunitas Arab di zaman permulaan Islam

Dalam al-Qur'an menetapkan pelarangan minum khamar mulai dari menyentuh secara halus bahwa didalam khamar terdapat manfaat yang memberi kesengan kepada peminumnya, namun menyadarkan bahwa mudharatnya lebih bear. Dalam al-Qur'an Allah berfirman (2: 219)
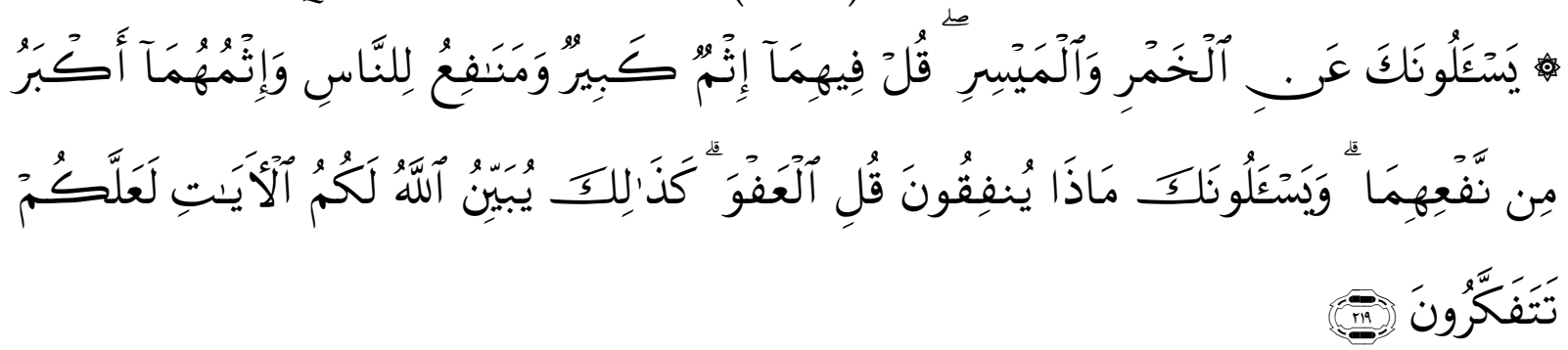

Artinya:

mereka bertanya kepadamu tentang khamar, dan judi. Katakanlah: "Pada keduanya terdapat dosa yang besar dan beberapa manfaat bagi manusia, tetapi dosa keduanya lebih besar dari manfaatnya". dan mereka bertanya kepadamu apa yang mereka nafkahkan. Katakanlah: " yang lebih dari keperluan." Demikianlah Allah menerangkan ayat-ayat-Nya kepadamu supaya kamu berfikir.

Pada tahap selanjtnya, al-Qur'an menggunakan secara persuasif, yaitu pencegahan untuk tidak boleh shalat dalam keadaan mabuk, dalam al-Qu'an Allah berfirman ( $4: 43)$

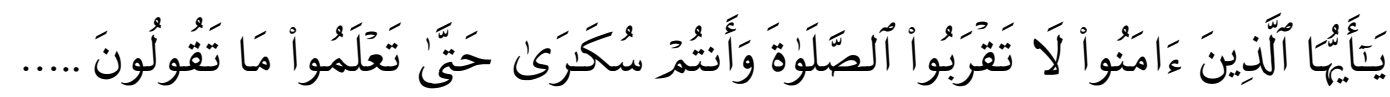

Artinya:

Hai orang-orang yang beriman, janganlah kamu shalat, sedang kamu dalam Keadaan mabuk, sehingga kamu mengerti apa yang kamu ucapkan...... 
Jika tahap ini tidak diindahkan maka langkah tegas untuk memberi kesempatan akal merenungkan hukum di akibatkan agar meninggalkan mudharat telah Allah swt. siapkan untuk menyadarkan manusia. Allah berfirman dalam alQur'an (5: 90)

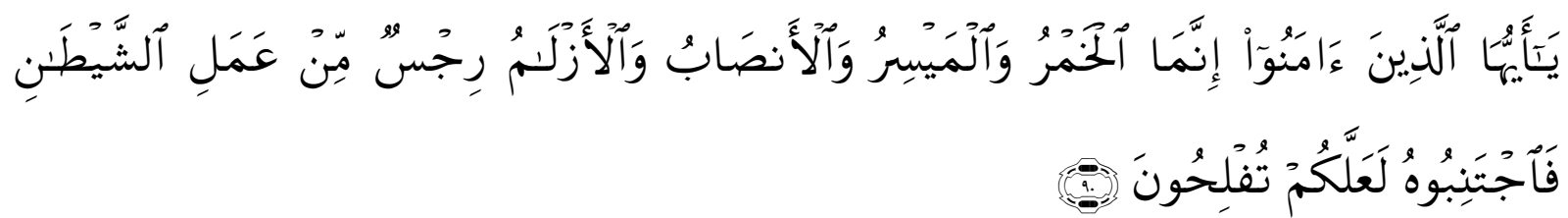

Artinya:

Hai orang-orang yang beriman, Sesungguhnya (meminum) khamar, berjudi, (berkorban untuk) berhala, mengundi nasib dengan panah [434], adalah Termasuk perbuatan syaitan. Maka jauhilah perbuatan-perbuatan itu agar kamu mendapat keberuntungan. ${ }^{18}$

Muhammad Qutub dalam hal ini berpendapat, bahwa untuk menanamkan kebiasaan yang baik, al-Qur'an menganjurkan untuk menyenangi lebih dahulu, kemudian mempelajari dan setelah itu baru berusaha melaksanakannya dalam kehidupan. Dan akhirnya kebiasaan dilakukan berdasarkan keyakinan agama tersebut berubah menjadi aktivitas rutin yang ringan. Keitannya dengan pemberlajaran orang dewasa, penahapan pembentukan kebiasaan jiga harus di awali dengan penanaman konsep secara rasional terhadap kebermanfatannya dalam situasi kerja.

\section{Metode Praktik}

Metode praktik sangat dibutuhkan untuk aplikasi metode pemahaman dan penyadaran. Sebab dari pemahaman akan munculnya kesadaran dan kesadaran menjadi landasan dalam beramal. Metode ini dalam pendidikan Islam dapat berupa penugasan dan keteladanan. Al-Qur'an menganjurkan agar perbuatan didasari pengetahuan, sehingga perilaku manusia adalah perilaku Amali dan dapat dipraktikkan secara langsung denga orang lain. Keteraturan hubungan manusia dengan lingkungan, toleransi terhadap sesamnya serta pengorbanan sosial membutuhkan latihan yang rutin.

5. Metode Pembelajaran dalam Hadits Nabi saw.

Membahas metode pembelajaran dalam pendidikan Islam tidak lepas dari

18 [434] Al Azlaam artinya: anak panah yang belum pakai bulu. orang Arab Jahiliyah menggunakan anak panah yang belum pakai bulu untuk menentukan Apakah mereka akan melakukan suatu perbuatan atau tidak. Caranya Ialah: mereka ambil tiga buah anak panah yang belum pakai bulu. setelah ditulis masing-masing Yaitu dengan: lakukanlah, jangan lakukan, sedang yang ketiga tidak ditulis apa-apa, diletakkan dalam sebuah tempat dan disimpan dalam Ka'bah. bila mereka hendak melakukan sesuatu Maka mereka meminta supaya juru kunci ka'bah mengambil sebuah anak panah itu. Terserahlah nanti Apakah mereka akan melakukan atau tidak melakukan sesuatu, sesuai dengan tulisan anak panah yang diambil itu. kalau yang terambil anak panah yang tidak ada tulisannya, Maka undian diulang sekali lagi. 
fungsi Nabi Muhammad saw. Sebagai pendidik yang menerapkan metode mengajara dalam pengembangan risalah dalam berdakwah.t

Untuk mengetahui metode pembelajaran yang dikembangkan oleh Nabi Muhammad saw. Maka dapat dicermati melalui berbagai term seperti; tarbiyah, ta'dib, at-ta'lim. Proses pembinaan spritual anak lebih efektif lagi bila dalam usia dininya ini, dilatih un tuk ibadah. Kemudian pada umur tujuh tahun sebagaimana dalam hadits tadi, hendaknya mereka diperintahkan untuk mendirikan shalat secara kontinyu. Ketika mereka mencapai uur sepuluh tahun dan ketika itu pula mereka meninggalkan shalat, maka hendaklah diberi sanksi fisik berupa hukuman.

\section{g. Paradigma Pendidikan Islam}

Paradigma Pendidikan Islam dapat berarti; pola, corak, model atau wawasan tentang pendidikan Islam.Untuk menguraikan hal tersebut di atas maka perlu menggunakan filosofis yang meliputi ontologi, epitimologi dan aksiologi.

1. Ontologi pendidikan agama Islam

Ada tiga pertanyaan dalam filsafat selalu digunakan, yaitu "Apa hakekat yang ada" bagaimana keadaan hakekat" dan dimana hakekat kenyataan ini adalah beberapa pertanyaan ontologis sebagai landasan untuk memantapkan batas ruang lingkup wujud yang menjadi objek kajian dan penafsiran terhadap realitas.

Melihat pendidikan dalam perspektif ontologi adalah upaya menjawab hakikat pendidikan dalam Islam. Hakekat pendidikan secara filosofis adalah upaya pemanusiaan manusia dengan cara-cara yang manusiawi untuk mencapai nilai-nilai kemanusiaan. Perpaduan dari uraian hakikat pendidikan dan manusia maka pendidikan Islam dalam persfektif ontologis dapat di verbalisasikan dalam sebuah konsep yaitu suatu proses atau upaya terprogram dari pendidikan untuk membantu peserta didik dalam mencapai nilai-nilai noematif sedsuai dengan ajaran Islam

2. Epistimologi Pendidikan dalam Islam

Epistemologi Pendidikan dalam Islam yang terpenting dalam dunia filsafat yang menyelidiki asal-mula, susunan, metode dan keabsahan pengetahuan. Gambaran defenisi ini memunculkan pertanyaan yang mendasar: Apakah pengetahuan itu? Dari mana asal mula pengetahuan itu? Bagaimana corak dan bentuk pengetahuan itu? Bagaimana cara memperoleh pengetahuan dan lain-lain.

Berangkat dari definisi pendidikan adalah bimbingan, kepemimpinan, secara sadar oleh pendidik terhadap perkembangan yang terjadi pada peserta didik, baik jasmani maupun ruhani menuju terbentuknya kepribadian yang utama. Kata pendidikan pada awalnya berasal dari bahasa yunani, yaitu pedagogie yang terdiri atas dua kata, paes (paid) dan agogus Kata paes berarti anak dan kata agogus berarti aku membimbing, jadi pendidikan secara etimologis selalu dihubungkan dengan kegiatan bimbingan terutama kepada anak, karena anaklah menjadi obyek yang dididik. 


\section{Aksiologi Pendidikan dalam Islam}

Aksiologi adalah ilmu pengetahuan yang membahas tentang hakikat nilai yang ditinjau dari sudut kefilsafatan. Dalam aksioogi berfungsi untuk menilai hakekat sebuah kenyataan sedangkan nilai yang baik, etika, logika dan estetika adalah bagian dari aksiologi. Sementara nilai yang diinternalisasikan kepada peserta didik sesuai dengan aliran pendidikan, diantaranya:

1. Aliran Progresivisme.

Menurut aliran ini dalam proses pendidikan tidak ada suatu nilai yang baku untuk dicapai sesuai dengan tujuannya. Oleh karena itu menurut aliran ini nilai yang diinternalisasikan masih terbatas pada nila-nilai insaniyah. Ontologi aliran ini tercermin dalam kebebasan dan kemerdekaan peserta didik untuk berinisiatif, percaya diri serta mampu mengembangkan bakat dan waktunya yang terpendam. Aliran ini meletatakkan pengalaman sebagai ciri khasnya, karena pengalaman memegang peran pending dalam kehidupan untuk mengatasi segala perubahan. dengan pengalaman berarti ia memilki potensi dinamis untuk berkembang. Dalam hal ini pendidik lebih banyak memberikan perhatian terhadap peserta didik.

2. Aliran Esensialisme.

Menurut aliran ini, dalam proses pendidikan setidaknya ada tiga nilai yang harus ada dan diinternalisasikan kepada peserta didik, yaitu: nilai etik, logika, dan estetika. Pandangan aliran ini lebih maju dari aliran sebelumnya, yang hanya mengakui nilai empiris. Ontologi aliran ini adalah berupaya memlihara nilai-nilai pokok yang bersifat konstan yang mampu memberikan kestabilan. Mereka beranggapan bahwa nilai tersebut telah terbukti dapat memberikan sumbangan berharga bagi keberlangsungan masyarakat. Kelompok ini menekankan pada adanya prinsip yang menjadi pedoman sehingga pendidikan jadi stabil.

3. Prenialisme.

Aliran ini merupakan kelanjutan dari aliran esensialisme yang berarti abadi. Esensi ajaran yang dikembangkan dalam aliran ini adalah nilai dan norma yang bersifat abadi. ${ }^{19}$ Ontologi pendidikanaliran ini menekankan pentingnya untuk kembali kepada asas dan nilai tatanan masa silam yang di anggap abadi dan mempesiapkan masa yang akan datang, sehingga mampu melahirkan kembali pemikiran dan pemikir sekaliber pemikir masa lalu. Asas dan nilai tersebut adalah metafisika, logika dan estetika.

Menurut aliran ini proses pendidikan harus terinternalisasi nilai-nilai yang abadi kepada peserta didik yang meliputi, nilai etik, logika, estetika dan agamis. Sehingga dalam pandangan ini kebajikan yang tertinggi adalah penyatuan diri

${ }^{19}$ Mohammad Noor Syam, Filsafat Pendidikan dan Dasar filsafat pendidikan pancasila (Surabaya: Usaha Nasional, 1986) h. 298. 
dengan Tuhan. Oleh karena itu aliran ini berupaya menginternalisasikan nilai-nilai insaniyah dan ilahiyah secara simultan terhadap peserta didik.

h. Persamaan dan perbedaan Andragogi dalam pendidikan Islam.

Dalam berbagai uraian di atas dapatlah dikemukakan persamaan dan perbedaan antara andragogi dalam pendidikan Islam.

\section{Persamaan}

a. Konsep tentang pendidikan

Sama- sama beranjak dari konsep pendidikan dalam tinjauan filosofis yang bermuara pada ontologi, epistimologi dan aksiologi yang berkaitan dengan unsur-unsur edukatif yang sekaligus sebagai konsep bahwa pendidikan adalah suatu usaha, usaha itu dilakukan secara sadar, usaha itu di lakukan oleh-orangorang yang bertanggung jawab kepada masa depan, usaha ini mempunyai dasar dan tujuan, usaha perlu dilakukan secara teratur dan sistimatis.

b. Konsep tentang peserta didik

Sama-sama menganggap peserta didik sebagai objek dan subjek didik yang perlu dikembangkan ke arah peningkatan pengetahuan, sikap dan keterampilan. Dalam pembelajran peserta didik memiliki hak dan kewajiban untuk diberlakukan sama tanpa terbatasi oleh usia dan status sosial lainnya. Peserta didik merupakan manusia hamba Allah SWT, yang mempunyai tugas dan fungsi sebagai khalifah di bumi.

c. Konsep Tentang Pendidik

Sama-sama memposisikan pendidik sebagai subjek didik yang mengarah objek didik untuk mencapai tujuan yang diinginkan. Pendidik dalam posisi seperti ini berperan sebagai pembimbing, sikap pembimbing yang dibutuhkan yaitu; empati, kewajaran, respek, komitmen dan kehadiran, membuka diri, tidak diskriminatif dan penampilan bersimpatik.

d. Metode pembelajaran

Sama-sama mengakui bahwa metode pembelajran yang digunakan dalam mengajar anak-anak (pedagogi) harus berbeda dengan mentode digunakan untk mengajar orang dewasa (andragogi) oleh sebab itu keduanya mengedepankan metode konstruktif.

\section{Perbedaan}

Perbedaan menonjol antara andragogi dalam pendidkan Islam yakni terletak pada sumber, metode, penerapan metode, media pembelajaran, dan orientasi materi pembelajaran. Kekurangan andragogi versi pendidikan barat adalah terkait dengan

\section{i. Upaya Pengembangan Metode Andragogi}

Dari uraian di atas maka upa yang dilakukan untuk mengembangan andragogi yang berbasis pendidikan Islam adalah dengan menggunakan inseminasi ide melalui 
sistem pelatihan. Oleh karena itu pengembangan Andragogi berbasis Pendidikan Islam dapat diinseminasikan dengan pendekatan teori internalisasi nilai. Inseminasi dalam konteks ini dimaksudkan sebagai upaya penggabungan ide tentang konsep metode pembelajaran yang bersumber dari hasil pemikiran. Islam melihat bahwa proses internalisasi nilai yang paling efektif adalah melalui tiga cara yaitu: perkataan, perbuatan, dan penetapan/ persetuuan.

\section{G. PENUTUP}

Pandangan tentang pendidikan yang dirumuskan sebagai upaya mentrasmisikan pengetahuan yang melahirkan teori pembelajaran "pedagogi" sudah tidak tepat lagi digunakan di tengah berbagai perubahan yang terjadi di abad modern, sehingga lahir pandangan pendidikan yang dirumuskan sebagai proses pendidikan sepanjang hayat. Dari ide baru inilah terlahir konsep tentang andragogi.

Andragogi adalah seni dan ilmu mengajar orang dewasa dalam belajar, cara membantu orang dewasa belajar dengan menggunkan pengalamannya. Jadi andragigi adalah metode pembelajaran yang digunakan bagi pendidikan orang dewasa.

Asumsi-asumsi tentang andragogi yaitu konsep diri tentang peserta didik, peranan pengalaman, kesiapan utuk belajar, dan orientasi belajar. Langkah-langkah pokok adalah menciptakan iklim belajar yang kondusif, diagnosis kebutuhan belajar, proses perencanaan, memformulasikan tujuan, pengembangan model umum, penetapan materi dan teknik pembelajaran, serta melakukan evaluasi pembelajran.

Prinsi-prinsip pembelajaran andragogi meliputi, kesiapan untuk belajar, tahap belajar, pemahaman, peran serta, umpan balik, pemantapan, dorogan untuk belajar (motivasi) Apresepsi, penerapan, dan alih belajar.

Berangkat dari pandangan Islam tentang hakekat manusia terdiri dari unsur jasad dan ruh maka nilai yang akan diintrnalisasikan dalam pembelajaran menyangkut dua hal yakni nilai-nilai insaniyah dan nilai-nilai ilahiyah, nilai insaniyah bersumber dari potensi dasar manusia yaitu daya cipta, rasa, dan karsa, yang bersifat dinamis, nisbi dan temporal, sementara nilai ilahiyah bersumber dari ayat-ayat Allah baik Qur'ani maupun kauni yang bersifat mutlak dan abadi.

\section{Daftar Pustaka}

Al- Qur'an dan Terjemahnya

Arif, Zainuddin, Andragogi, cet. II; Bandung: Angkasa. 1994

Badan Litbang Agama dan Diklat Keagamaan Departemen Agama R.I. "Pendekatan Andragogi dalam Diklat, Jakarta: Pusdiklat tenaga Teknis Keagamaan, 20013

Bambang S. dan Lukman, "Teori belajar Andragogi" Pendidikan network-MSIUII.Net, 23 Maret 2007. 
Departemen Pendidikan dan kebudayaan Republik Indonesia. Kamus Besar Bahasa Indonesia, Cet. I; Jakarta: Perum Balai Pustaka. 1988.

DePorter, Bobbi dan Mark Reardon Sarah Singer-Nourie “Quantum Teaching "Memperaktiukkan Quanrum Learning diruang-ruang kelas, Bnadung, Kaifa 2010.

Drajat, Zakiah, dkk., Ilmu pendidikan Islam, cet. V; Jakarta: Bumi Aksara, 2004.

Finger, Marthias, dan Jose Manuel Asun, Adult Education at theCrossroads, diterjemahkan oleh Nining Fatikasari dengan judul Quo vadis pendidikan orang dewasa cet. I; Yogyakiarta; Pustaka Kendi, 2004

J. Havingurst masa dewasa dibagi tiga fase yaitu: dewasa awal 18-30 tahun, dewasa pertengahan 30-55 tahun, dewasa akhir 55< tahun, lihat W.S. Winkel psikologi pengajaran Jakarta: Grasindo), 1991.

Knowles, Malcom, The Modern Practise of Adult Education Andragogi Versus Pedagogy, New York: Assosiation Press, 1077

Lunadi, A.G. Pendidikan Orang Dewasa, Cet. VII; Jakarta: PT. Gramedia Pustaka Utama 1993

M. Thoyib, Pengantar Pendidikan orang dewasa Jakarta: Depsos R.I., 2006.

Nasution, S. “Didaktik Asas-Asas Mengajar (Jakarta: Bumi Aksara, 2000)

Noor Syam, Mohammad "Filsafat Pendidikan dan Dasar filsafat pendidikan pancasila" (Surabaya: Usaha Nasional, 1986).

Supriadi, "Andragogi (sebuah Konsep teoritik) Pendidikan Network, MSI - UII, Net 21 Maret 2006

Shuhab, M. Quraish, Tafsir al-Misbah Pesan, Kesan dan keserasian al-Qur'an cet.III; Jakarta Lentera Hati, 2007.

Tamat Ny. Tisnowaqti, Dari pedagogik ke andragogik, Jakarta: Pustaka Dian, 1983.

Tafsir, Ahmad, Ilmu Pendidikan dalam perspektif Islam, Bandung: Remaja Rosda Karya, 1994 